\title{
PENGARUH LABA PER SAHAM, NILAI BUKU EKUITAS DAN ARUS KAS OPERASI TERHADAP HARGA SAHAM
}

\author{
Yumna Puspita \\ UPN "Veteran" Jakarta \\ yumna_puspita94@yahoo.com \\ Samin \\ UPN "Veteran" Jakarta \\ samin58@ymail.com
}

\begin{abstract}
This study was conducted to examine the effect of variable Earning Per Share, Book Value of Equity, and Cash Flow of Operation on the Stock Price in manufacture sector listed on the Indonesia Stock Exchange (IDX) during the period 2012-2014. The data obtained in this study were published financial statements. The population in this study amounted to 44 companies and 132 samples obtained from 44 companies during the 3 years of observation. Techniques in sampling using purposive sampling method. The analysis technique used is multiple linear regression to examine the effect between dependent and independent variables and hypothesis testing using the simultan test and parsial test with a confidence level of 5\%. The results showed that simultaneous Earning Per Share, Book Value of Equity, and Cash Flow of Operation have a significant effect on the Stock Price. While the partial test results showed that Earning Per Share, book value of Equity and Cash Flow of Operation have significant effect on the Stock Price.

Keywords : Earning Per Share, Book Value of Equity, and Cash Flow of Operation
\end{abstract}

\section{PENDAHULUAN}

Laporan keuangan merupakan informasi penting yang dihasilkan dari proses akuntansi pada suatu perusahaan. Tujuannya adalah untuk menyediakan informasi mengenai posisi keuangan dan kinerja perusahaan dalam suatu periode. Laporan keuangan yang dibuat dan diterbitkan oleh perusahaan harus dapat mengungkapkan kondisi perusahaan yang sesungguhnya sehingga informasi laporan keuangan tersebut dapat bermanfaat bagi penggunanya. Laporan keuangan dapat bermanfaat jika informasi laporan keuangan relevan.

Informasi akuntansi yang menjadi perhatian utama dan sebagai parameter yang mengikhtisarkan laporan keuangan adalah laba dan nilai buku perusahaan. Laba merupakan ukuran laporan laba rugi yang mengikhtisarkan imbal hasil, sedangkan nilai buku merupakan ukuran aktiva bersih perusahaan. Selain itu, informasi arus kas menjadi pusat perhatian bagi para pengguna laporan keuangan dalam menilai kinerja perusahaan. Pentingnya informasi arus kas di Indonesia ditandai dengan dikeluarkannya PSAK 2 tahun 2015 yang menyatakan bahwa perusahaan harus menyusun laporan arus kas dan harus menyajikan laporan tersebut sebagai bagian yang tidak terpisah dari laporan keuangan.

Informasi dalam laporan keuangan PT Gajah Tunggal Tbk (GJTL) belum maksimal digunakan oleh para investor sebagai dasar pertimbangan untuk mengambil keputusan dalam berinvestasi. Hal ini dapat terlihat dari kinerja perusahaan yang mengalami kenaikkan dari tahun 2013 ke 2014 pada laba bersih dan jumlah ekuitas sehingga membuat laba per saham dan nilai buku ekuitas perusahaan meningkat. Namun harga saham PT Gajah Tunggal Tbk (GJTL) mengalami penurunan. Selain itu, pada PT Astra Internasional Tbk (ASII). Kinerja perusahaan tahun 2013 ke 2014 mengalami penurunan ditandai dengan turunnya laba bersih dan arus kas operasi serta total arus kas. Namun harga saham ASII mengalami peningkatan. 


\subsection{Teori Clean Surplus}

Informasi akuntansi yang relevan harus disampaikan oleh manajemen kepada pengguna laporan keuangan agar laporan keuangan dapat bermanfaat bagi para pengguna laporan keuangan dalam mengambil keputusan. Berdasarkan teori clean surplus, ohlson menyatakan bahwa nilai pasar perusahaan tercermin dalam data-data akuntansi yang terdapat di laporan keuangan yaitu pada komponen laporan laba rugi dan neraca (Scott 2011, hlm.209).

Menurut Wirama (2008) hasil valuasi teori surplus bersih dapat digunakan sebagai dasar untuk mengidentifikasi perusahaan yang sahamnya di pasar modal sedang dalam kondisi terharga lebih (overpriced) atau terharga kurang (underpriced). Harga saham suatu perusahaan yang ditransaksikan harganya terharga lebih (overpriced), maka investor disarankan untuk menghindari investasi pada saham tersebut atau menjual saham tersebut. Namun, jika harga saham suatu perusahaan yang ditransaksikan harganya terharga kurang (underpriced), maka investor disarankan untuk segera membeli saham tersebut atau ditahan bila telah memiliki saham tersebut.

Sehingga teori clean surplus mengemukakan data-data akuntansi memiliki manfaat dalam penilaian ekuitas yang dimiliki perusahaan. Hubungan antara nilai saham perusahaan dan informasi akuntansi digunakan sebagai dasar pengembangan model-model valuasi dalam teori surplus bersih.

\subsection{Teori Pasar Efisien}

Setiap investor selalu menginginkan setiap perusahaan memberikan informasi yang terbuka dan akurat. Sehingga tidak munculnya informasi yang bias.

Menurut Fahmi (2012, hlm.260) Pasar efisien adalah suatu kondisi dimana informasi tentang semua harga dapat diperoleh secara terbuka dan cepat tanpa ada hambatan yang khusus. Teori ini memprediksikan bahwa harga sekuritas yang diperdagangkan pada setiap waktu secara wajar merefleksikan semua informasi terkait dengan harga sekuritas tersebut yang diketahui oleh publik (Scott 2011, hlm.110).

Hal yang diperhatikan dalam mengukur pasar efisien secara informasi yaitu dengan menghubungkan harga sekuritas dengan informasi yang telah dipublikasikan. Suatu pasar yang efisien berdasarkan nilai intrinsik sekuritas didefinifikan sebagai pasar yang nilainilai sekuritasnya tidak menyimpang dari nilai-nilai intrinsiknya (Jogiyanto 2010, hlm.503).

Soewardjono (2010, hlm.489) membedakan bentuk pasar efisien kedalam tiga bentuk efisiensi, yaitu:

a. Efisien dalam bentuk lemah (weak form). Pasar efisien dalam bentuk lemah jika harga sekuritas merefleksikan secara penuh informasi harga dan volume sekuritas masa lalu (yang biasanya tersedia secara publik). Pelaku pasar masih dimungkinkan untuk memperoleh return abnormal dengan memanfaatkan informasi selain data pasar.

b. Efisien dalam bentuk setengah kuat (semistrong form). Dikatakan pasar efisien bentuk semikuat jika harga sekuritas merefleksikan secara penuh semua informasi yang tersedia secara publik termasuk data statement keuangan. Karena semua pelaku pasar memperoleh semua akses yang sama terhadap informasi publik, strategi informasi yang mengandalkan statement keuangan publikasi tidak akan mampu menghasilkan return abnormal secara terus-menerus.

c. Efisien dalam bentuk kuat (strong form), pasar efisien dalam bentuk kuat, semua informasi baik yang terpublikasi atau tidak dipublikasikan, sudah tercermin dalam harga sekuritas saat ini.

Dalam teori ini reaksi investor yang cepat terhadap informasi yang diperoleh dapat digunakan untuk mengukur manfaat dari informasi. Oleh karena itu, begitu informasi perusahaan tersedia di publik, maka informasi tersebut akan direspon oleh pasar secara cepat dan tepat yang akan langsung tercermin dalam harga saham. 


\subsection{Teori Signaling}

Informasi yang disampaikan manajemen harus lengkap, relevan, dan akurat agar informasi tersebut dapat membantu para investor dalam mengambil keputusan. Teori sinyal membahas naik turunnya harga di pasar, sehingga memberikan pengaruh pada keputusan investor (Fahmi 2012, hlm.100).

Sinyal merupakan suatu tindakan yang diambil oleh manajemen suatu perusahaan untuk memberikan petunjuk kepada investor tentang bagaimana manajemen menilai prospek perusahaan tersebut (Brigham \& Houston 2011, hlm 186).

Godfrey, Hodgson, Tarca, Hamilton \& Holmes (2010, hlm.376) menjelaskan bahwa manajemen perusahaan menggunakan laporan keuangan untuk memberi sinyal harapan dan prediksi mengenai masa depan. Maka dari itu, pihak manajer menjadi harapan besar pemilik dalam memberikan informasi mengenai prospek pertumbuhan perusahaan kedepannya.

Sehingga disimpulkan bahwa teori sinyal adalah tindakan manajemen dalam memberikan sinyal mengenai keadaan perusahaan kepada pengguna laporan keuangan. Salah satu jenis informasi yang dikeluarkan oleh perusahaan yang dapat menjadi sinyal bagi pihak investor adalah laporan tahunan. Salah satu isi dari laporan tahunan berupa informasi laporan keuangan. Pengumuman informasi akuntansi dari manajemen akan memberikan sinyal sebagai sinyal baik (good news) atau sinyal buruk (bad news). Sinyal good news menandakan bahwa informasi akuntansi memberikan signal mengenai perusahaan mempunyai prospek yang baik di masa mendatang dan sinyal bad news menandakan bahwa perusahaan perusahaan mempunyai prospek yang buruk di masa mendatang. Jika sinyal yang dipublikasikan berupa good news, maka sinyal tersebut dapat berpengaruh meningkatkan harga saham. Namun, jika sinyal yang dipublikasikan berupa bad news, maka dapat menurunkan harga saham.

\subsection{Pengaruh Laba Per Saham Terhadap Harga Saham}

Laba mempunyai kandungan informasi yang penting bagi investor. Maka dari itu, laba menjadi informasi perusahaan yang paling diminati. Besarnya laba per saham suatu perusahaan dapat diketahui dari informasi laporan keuangan perusahaan. Suwardjono (2010, hlm.484) menyatakan kebermanfaatan laba dapat diukur dari hubungan antara laba dan harga saham. Dikeluarkannya PSAK 56 tahun 2015 yang menyatakan prinsip penentuan dan penyajian laba per saham untuk meningkatkan daya banding kinerja antar entitas yang berbeda pada periode pelaporan yang sama, dan antar periode pelaporan berbeda untuk entitas yang sama. Maka dari itu, semakin tinggi nilai laba per saham menyebabkan semakin besar laba yang diperoleh sehingga perusahaan menyajikan kinerja yang baik dan membuat nilai perusahaan dimata investor meningkat serta investor tertarik untuk berinvestasi. Dengan demikian, permintaan saham perusahaan akan meningkat. Peningkatan permintaan akan mengakibatkan naiknya harga saham perusahaan.

Penelitian Adhani \& Subroto (2014) memberikan hasil bahwa adanya hubungan signifikan positif earning per share dan Hasil penelitian ini juga menunjukkan bahwa di sektor property dan real estate, informasi akuntansi berupa earnings lebih relevan untuk digunakan dibandingkan informasi akuntansi lainnya pada model yang diuji.

Penelitian yang dilakukan oleh Shamki \& Rahman (2012) menemukan bahwa earnings lebih penting dalam menjelaskan variance pada harga saham dibandingkan dengan book value.

Berdasarkan data diatas maka, dapat diperoleh hipotesis sebagai berikut :

$\mathbf{H}_{1}$ : Laba per saham berpengaruh signifikan terhadap harga saham

\subsection{Pengaruh Nilai Buku Ekuitas Terhadap Harga Saham}

Nilai buku ekuitas adalah rasio yang dihitung dengan membagi total ekuitas dengan jumlah saham yang beredar. Nilai buku menunjukan aset bersih (total ekuitas) yang dapat diperoleh dari total aset dikurangi dengan total hutang. Ekuitas dapat menggambarkan kesejahteraan pemegang saham, karena apabila ekuitas rendah yang diakibatkan 
banyaknya jumlah kewajiban (hutang), maka profit perusahaan akan dibatasi walaupun perusahaan melakukan begitu banyak bisnis. Sehingga hal ini akan mempengaruhi nilai perusahaan. Selain itu nilai buku dapat digunakan untuk memperkirakan batas bawah harga saham yang ditoleransi, karena dasar dari nilai buku ini dianggap sebagai batas aman atau ukuran safety plan dalam berinvestasi.

Nilai buku suatu perusahaan akan terus meningkat seiring dengan meningkatnya nilai perusahaan, demikian sebaliknya. Selain itu, nilai buku penting untuk mengetahui kapasitas dari harga per lembar suatu saham serta dalam penentuan wajar atau tidaknya harga saham di pasar.

Penelitian Indra \& Fazli (2004) memberikan hasil penelitian bahwa Pengujian untuk model harga secara simultan menunjukkan bahwa variabel nilai buku memiliki tingkat keeratan hubungan $\left(\mathrm{R}^{2}\right)$ yang sedang dengan harga saham. Penelitian Rosari (2004) memberikan hasil uji persamaan regresi menunjukkan nilai buku relevan terhadap harga saham dan nilai buku searah dengan harga saham.

Berdasarkan data diatas maka, dapat diperoleh hipotesis sebagai berikut :

$\mathbf{H}_{2}$ : Nilai Buku Ekuitas berpengaruh signifikan terhadap Harga Saham

\subsection{Pengaruh Arus Kas Operasi Terhadap Harga Saham}

Arus kas operasi merupakan arus kas masuk dan arus kas keluar yang berkaitan dengan kegiatan operasi perusahaan yang mempengaruhi laba atau rugi bersih perusahaan. Dikeluarkannya PSAK 2 tahun 2015 yang menyatakan jumlah arus kas dari aktivitas operasi yang cukup menggambarkan perusahaan tidak perlu mengandalkan penerbitan saham atau utang kepada pihak eksternal. Hal ini menunjukan bahwa dana yang diinvestasikan oleh investor dikelola secara efektif dan efisien oleh perusahaan. Sehingga nilai perusahaan dimata investor meningkat dan investor tertarik untuk berinvestasi. Dengan demikian, permintaan saham perusahaan akan meningkat. Peningkatan permintaan akan mengakibatkan naiknya harga saham perusahaan.

Hasil penelitian Susanto \& Ekawati (2006) menunjukan bahwa siklus hidup perusahaan mempengaruhi relevansi informasi laba dan aliran kas. Pada tahap start-up, aliran kas investasi dan aliran kas pendanaan mempunyai value relevance yang diukur dengan harga saham sedangkan laba, aliran kas operasi, aliran kas pendanaan mempunyai valuerelevance yang diukur pengan harga saham pada tahap growth. Pada tahap mature laba dan komponen aliran kas mempunyai value-revance yang diukur dengan harga saham sedangkan pada tahap decline aliran kas operasi dan aliran kas pendanaan yang mempunyai value-relevance yang diukur dengan harga saham.

Penelitian Sari (2004) menunjukan bahwa ada saat-saat tertentu yang membuat laba tidak lagi memiliki relevansi nilai, dan pada saat perusahaan merugi maka yang dapat digunakan untuk menilai perusahaan adalah informasi arus kas operasi.

Berdasarkan data diatas maka, dapat diperoleh hipotesis sebagai berikut :

$\mathbf{H}_{3}$ : Arus Kas Operasi berpengaruh signifikan terhadap Harga Saham

\section{METODE PENELITIAN}

\subsection{Definisi Operasional}

a. Variabel Dependen (Y)

Variabel dependen dalam penelitian ini adalah harga saham. Harga pasar saham adalah harga suatu saham pada pasar yang sedang berlangsung. Jika bursa efek sudah tutup, maka harga pasar saham adalah harga penutupannya (closing price) (Hadi 2013, hlm.72).

b. Variabel Independen (X)

1) Laba Per Saham $\left(X_{1}\right)$

Prastowo (2011, hlm.99), menyatakan Laba per saham (Earning per Share) adalah jumlah laba yang menjadi hak untuk setiap pemegang satu lembar saham biasa.

2) Nilai Buku Ekuitas $\left(X_{2}\right)$ 
Nilai buku (book value) per lembar saham menunjukan aktiva bersih (net assets) yang dimiliki oleh pemegang saham dengan memiliki satu lembar saham (Jogiyanto 2010, hlm.120).

3) Arus Kas Operasi $\left(X_{3}\right)$

Arus kas dari aktivitas operasi yaitu nilai yang menunjukkan jumlah arus kas bersih dari aktivitas operasional perusahaan untuk setiap lembar saham yang dimiliki (Adhani \& Subroto 2014).

\subsection{Pengukuran Variabel}

a. Variabel Dependen (Y)

Pada penelitian ini harga saham yang digunakan adalah harga saham penutupan pada tanggal 5 hari setelah laporan keuangan dipublikasi oleh Bursa Efek Indonesia (BEI).

b. Variabel Independen (X)

1) Laba Per Lembar Saham $\left(X_{1}\right)$

Berdasarkan Tandellin (2010, hlm.374).

$$
\text { EPS }=\frac{\text { EAT }}{\text { Jumlah saham yang beredar }}
$$

2) Nilai Buku Ekuitas $\left(X_{2}\right)$

Menurut Jogiyanto (2010, hlm.120)

Total Ekuitas

$\mathrm{NBE}=$

Jumlah Saham Beredar

3) Arus Kas Operasi $\left(X_{3}\right)$

Berdasarkan (Adhani \& Subroto 2014).

Arus Kas Bersih Operasi

\subsection{Populasi dan Sampel}

Jumlah Saham Beredar

Objek penelitian yang digunakan dalam penelitian ini adalah seluruh perusahaan sektor manufaktur yang menerbitkan laporan keuangan yang terdaftar di Bursa Efek Indonesia (BEI) selama periode pengamatan 2012-2014. Sampel penelitian ini ditentukan dengan metode purposive sampling dan diperoleh sebanyak 44 perusahaan sebagai sampel penelitian.

Tabel 1 Proses Seleksi Sampel Bedasarkan Kriteria

\begin{tabular}{llc}
\hline \multicolumn{1}{c}{ Keterangan } & $\begin{array}{c}\text { Jumlah } \\
\text { Perusahaan }\end{array}$ \\
\hline & $\begin{array}{l}\text { Perusahaan sektor manufaktur yang listing di Bursa Efek } \\
\text { Indonesia (BEI) selama periode 2012 sampai 2014. }\end{array}$ & 142 \\
\hline & $\begin{array}{l}\text { Perusahaan yang tidak dapat digunakan: } \\
\text { 1) }\end{array}$ & \\
& Perusahaan yang tidak listing selama tiga tahun berturut- \\
turut & $(12)$ \\
2) & $\begin{array}{l}\text { Perusahaan mengalami rugi, ekuitas negatif dan arus kas } \\
\text { operasi negatif dari tahun 2012-2014 }\end{array}$ & $(62)$ \\
3) & Perusahaaan yang tidak memiliki kelengkapan data & $(5)$ \\
4) & Perusahaan menggunakan mata uang asing & $(19)$ \\
\hline & Jumlah Perusahaan yang menjadi sampel & 44 \\
\hline & Periode Penelitian (tahun) & 3 \\
\hline & Jumlah Sampel Penelitian & 132 \\
\hline Sumber: www.idx.co.id
\end{tabular}


Berdasarkan proses seleksi sampel dengan kriteria yang telah ditetapkan (purposive sampling), maka diperoleh 44 perusahaan manufaktur yang akan dijadikan sampel dengan periode pengamatan selama 3 tahun.

\subsection{Analisis Deskriptif}

Berdasarkan hasil pengolahan data dengan menggunakan SPSS versi 20,0 diperoleh hasil perhitungan sebagai berikut:

Tabel 2 Hasil Statistik Deskriptif

\begin{tabular}{llrrrr}
\hline & $\mathrm{N}$ & \multicolumn{1}{c}{ Mini } & \multicolumn{1}{c}{ Max } & \multicolumn{1}{c}{ Mean } & \multicolumn{1}{c}{ Std. Deviation } \\
\hline Harga Saham & 132 & 96.00 & 1102000.00 & 34430.1742 & 138058.32246 \\
Laba Per Saham & 132 & 1.24 & 17989.77 & 1323.5620 & 3370.89551 \\
Nilai Buku Ekuitas & 132 & 124.26 & 47740.25 & 4759.2498 & 9182.42905 \\
Arus Kas Operasi & 132 & .40 & 21776.56 & 1301.9273 & 3581.02931 \\
Valid N (listwise) & 132 & & & & \\
\hline
\end{tabular}

Sumber: Data diolah dari SPSS 20

Dari tabel 2 diatas diketahui bahwa jumlah sampel digunakan dalam penelitian ini adalah sebanyak 44 sampel dengan periode penelitian selama 3 tahun, maka jumlah $\mathrm{N}=132$. Selain itu dengan mengacu tabel yang sama, diketahui bahwa nilai harga saham terendah Rp 96 terdapat pada Budi Acid Jaya Tbk (BUDI) pada tahun 2015, hal ini menunjukkan bahwa Budi Acid Jaya Tbk (BUDI) pada tahun 2015 setelah tanggal publikasi memiliki rata-rata harga saham selama 5 hari sebesar Rp 96. Nilai tertinggi harga saham sebesar Rp 1.102.000 terdapat pada Multi Bintang Indonesia Tbk (MLBI) pada tahun 2014, hal ini menunjukkan bahwa rata-rata 5 hari harga saham setelah tanggal publikasi pada tahun 2014 Multi Bintang Indonesia Tbk (MLBI) sebesar Rp 1.102.000. Nilai rata-rata sebesar Rp 34.430,17, hal ini menunjukkan bahwa harga saham pada perusahaan dalam sektor manufaktur yang menjadi objek penelitian pada tahun 2013 sampai 2014 sebesar Rp $34.430,17$. Pada penelitian ini variabel harga saham memiliki nilai rata-rata Rp 34.430,17 lebih rendah dari standar deviasi sebesar $\mathrm{Rp}$ 138.058,32 sehingga rata-rata jarak penyimpangan titik-titik data diukur dari nilai rata-rata data lebih jauh dan semakin menunjukan data penelitian heterogen.

Laba per saham (Earning Per Share) yang diukur dengan membagi laba bersih dengan jumlah saham yang beredar memiliki nilai terendah sebesar Rp 1,24 terdapat pada Budi Acid Jaya Tbk (BUDI) pada tahun 2012, hal ini menunjukkan kemampuan perusahaan untuk memberikan keuntungan perusahaan kepada pemegang saham sebesar Rp 1,24 setiap lembarnya. Nilai tertinggi sebesar Rp 17.989,77 terdapat pada Delta Djakarta Tbk (DLTA) pada tahun 2014, hal ini menunjukkan kemampuan perusahaan untuk memberikan keuntungan perusahaan kepada pemegang saham sebesar Rp 17.989,77 setiap lembarnya. Nilai rata-rata sebesar Rp 1.323,56 menunjukkan bahwa kemampuan perusahaan untuk memberikan keuntungan perusahaan kepada pemegang saham sebesar Rp 1.323,56 pada setiap perusahaan yang menjadi objek penelitian. Pada penelitian ini

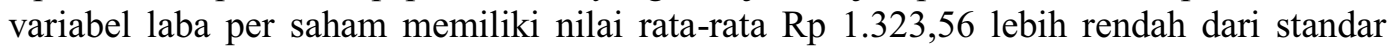
deviasi sebesar Rp 3.370,90 sehingga rata-rata jarak penyimpangan titik-titik data diukur dari nilai rata-rata data lebih jauh dan semakin menunjukan data penelitian heterogen.

Nilai buku ekuitas yang diukur dengan proksi membagi total ekuitas dengan jumlah saham beredar memiliki nilai terendah sebesar Rp124,26 terdapat pada Arwana Citra Mulia Tbk (ARNA) pada tahun 2014, hal ini menunjukkan aktiva bersih yang dimiliki oleh pemegang saham sebesar Rp 124,26 dalam setiap lembarnya. Nilai tertinggi sebesar Rp 47.740,25 terdapat pada Delta Djakarta Tbk (DLTA) pada tahun 2014, hal ini menunjukkan aktiva bersih yang dimiliki oleh pemegang saham sebesar Rp 47.740,25. Nilai rata-rata sebesar $\mathrm{Rp} 4.759,25$ menunjukkan bahwa seluruh perusahaan yang menjadi objek penelitian pada umumnya para pemegang saham dapat memperoleh aktiva bersih sebesar $\mathrm{Rp} 4.759,25$ pada setiap satu lembar saham dalam perusahaan sektor 
manufaktur. Data nilai buku ekuitas memiliki nilai rata-rata Rp 4.759,25 lebih rendah dari standar deviasi sebesar Rp 9.182,43 sehingga rata-rata jarak penyimpangan titik-titik data diukur dari nilai rata-rata data lebih jauh dan semakin menunjukan data penelitian heterogen.

Arus kas operasi diukur dengan membagi jumlah arus kas bersih operasi dengan jumlah saham beredar. Nilai terendah sebesar Rp 0,40 terdapat pada Budi Acid Jaya Tbk. (BUDI) pada tahun 2012, hal ini menunjukkan aktivitas operasi perusahaan sangat kecil menghasilkan arus kas untuk melunasi pinjaman, memelihara kemampuan operasi entitas, membayar dividen dan melakukan investasi baru tanpa bantuan dari sumber pendanaan dari luar, sehingga aktivitas operasional perusahaan yang dilakukan perusahaan kurang berjalan secara efektif dan efisien. Nilai tertinggi sebesar Rp 21.776,56 terdapat pada Delta Djakarta Tbk (DLTA) pada tahun 2013, hal ini menunjukkan aktivitas operasi perusahaan cukup menghasilkan arus kas untuk melunasi pinjaman, memelihara kemampuan operasi entitas, membayar dividen dan melakukan investasi baru tanpa bantuan dari sumber pendanaan dari luar, sehingga aktivitas operasional perusahaan yang dilakukan perusahaan berjalan secara efektif dan efisien. Nilai rata-rata sebesar Rp 1.301,93, menunjukkan bahwa seluruh perusahaan di sektor manufaktur yang menjadi objek penelitian ini pada tahun 2012 sampai tahun 2014 aktivitas operasi perusahaan cukup menghasilkan arus kas untuk melunasi pinjaman, memelihara kemampuan operasi entitas, membayar dividen dan melakukan investasi baru tanpa bantuan dari sumber pendanaan dari luar, sehingga aktivitas operasional perusahaan yang dilakukan perusahaan berjalan secara efektif dan efisien. Pada penelitian ini variabel arus kas operasi memiliki nilai rata-rata $\mathrm{Rp}$ 1.301,93 lebih rendah dari standar deviasi sebesar $\mathrm{Rp}$ 3.581,03 sehingga rata-rata jarak penyimpangan titik-titik data diukur dari nilai rata-rata data lebih jauh dan semakin menunjukan data penelitian heterogen.

\subsection{Analisis Asumsi Klasik}

\subsubsection{Uji Normalitas}

Hasil uji normalias dalam penelitian ini adalah sebagai berikut:

Tabel 3 Uji Normalitas One Sample Kolmogorov Smirnov

\begin{tabular}{|c|c|c|c|c|}
\hline & & Harga Saham & $\begin{array}{c}\text { Laba Per } \\
\text { Saham }\end{array}$ & $\begin{array}{l}\text { Nilai Buku } \\
\text { Ekuitas }\end{array}$ \\
\hline $\mathrm{N}$ & & 52 & 52 & 52 \\
\hline \multirow{2}{*}{ Normal Parameters $^{\mathrm{a}, \mathrm{b}}$} & Mean & 4744.1154 & 319.0381 & 1874.3508 \\
\hline & Std. Deviation & 3275.41704 & 233.19990 & 1487.51087 \\
\hline \multirow{3}{*}{$\begin{array}{l}\text { Most Extreme } \\
\text { Differences }\end{array}$} & Absolute & 186 & 178 & 188 \\
\hline & Positive & .186 & .178 & .188 \\
\hline & Negative & -.099 & -.127 & -.139 \\
\hline Kolmogorov-Smirnov Z & & 1.345 & 1.285 & 1.356 \\
\hline Asymp. Sig. (2-tailed) & & .054 & .073 & .051 \\
\hline
\end{tabular}

a. Test distribution is Normal.

b. Calculated from data.

Sumber: Data diolah dari SPSS 20

One-Sample Kolmogorov-Smirnov Test

\begin{tabular}{llrr}
\hline & & $\begin{array}{c}\text { Arus Kas } \\
\text { Operasi }\end{array}$ & \multicolumn{2}{c}{$\begin{array}{c}\text { Unstandardized } \\
\text { Residual }\end{array}$} \\
\hline $\mathrm{N}$ & & 52 & 52 \\
\multirow{2}{*}{ Normal Parameters ${ }^{\mathrm{a}, \mathrm{b}}$} & Mean & 328.1706 & $0 \mathrm{E}-7$ \\
& Std. Deviation & 297.37698 & 2162.82078710 \\
& Absolute & .181 & .133 \\
\multirow{2}{*}{ Most Extreme Differences } & Positive & .181 & .133 \\
& Negative & -.170 & -.120
\end{tabular}


Kolmogorov-Smirnov Z $\quad 1.307 \quad .963$

\begin{tabular}{lll} 
Asymp. Sig. (2-tailed) & .066 & .312 \\
\hline
\end{tabular}

a. Test distribution is Normal.

b. Calculated from data.

Sumber: Data diolah dari SPSS 20

Data ini sudah melalui tahap outlier

Hasil pengujian normalitas pada pengujian terhadap 52 data menunjukkan bahwa seluruh variabel sudah berdistribusi normal yang ditunjukkan nilai signifikansi pengujian Kolmogorov Smirnov sebesar 0,312 yang lebih besar dari 0,05. Secara parsial seluruh variabel sudah terdistribusi normal yang ditunjukan nilai signifikan pengujian Kolmogorov Smirnov harga saham sebesar 0,054, laba per saham sebesar 0,073, nilai buku ekuitas sebesar 0,051 dan arus kas operasi sebesar 0,066 yang lebih besar dari 0,05. Hal ini berarti bahwa nilai data telah terdistribusi dengan normal.

\subsubsection{Uji Multikolinieritas}

Hasil pengujian multikolinieritas dalam penelitian ini adalah sebagai berikut:

\begin{tabular}{|c|c|c|c|}
\hline \multirow[t]{2}{*}{ Model } & & \multicolumn{2}{|c|}{ Collinearity Statistics } \\
\hline & & Tolerance & $V I F$ \\
\hline \multirow{3}{*}{1} & $\begin{array}{l}\text { (Constant) } \\
\text { Laba Per Saham }\end{array}$ & .269 & 3.723 \\
\hline & Nilai Buku Ekuitas & .264 & 3.784 \\
\hline & Arus Kas Operasi & .319 & 3.135 \\
\hline \multicolumn{4}{|c|}{ a. Dependent Variable: Harga Saham } \\
\hline
\end{tabular}

Data ini sudah melalui tahap outlier

Dari hasil data pada tabel 4 menunjukkan bahwa nilai VIF untuk seluruh variabel independen memiliki nilai kurang dari 10 (VIF < 10) dan nilai Tolerance untuk seluruh variabel independen memiliki nilai lebih dari 0,10 . Hasil ini dapat disimpulkan bahwa variabel laba per saham, nilai buku ekuitas dan arus kas operasi tidak saling berhubungan ataupun tidak terkait satu sama lain sehingga model regresi dalam penelitian ini tidak menunjukan multikolinieritas.

\subsubsection{Uji Autokorelasi}

Hasil pengujian autokorelasi dalam penelitian ini adalah sebagai berikut:

Tabel 5 Hasil Uji Autokorelasi

Model Summary

\begin{tabular}{lll}
\hline Model & Durbin-Watson \\
\hline 1 & & 2.119
\end{tabular}

a. Predictors: (Constant), Arus Kas Operasi, Laba Per Saham,

Nilai Buku Ekuitas

b. Dependent Variable: Harga Saham

Sumber: Data diolah dari SPSS 20

Data ini sudah melalui tahap outlier

Dari hasil tabel 5 uji autokorelasi tersebut diketahui bahwa nilai Durbin Watson (DW) sebesar 2,119. Berdasakan tabel durbin watson dilihat dari $\mathrm{n}=52$, dan $\mathrm{k}=3$, maka didapatkan batas atas du sebesar 1,6769 dan 4-du sebesar 2,3231. Berdasarkan tabel diatas nilai DW penelitian ini adalah 2,119 dimana nilai tersebut terdapat 1,6769<2,119 $<2,3231$. Hasil ini menunjukan bahwa antara data tahun 2012, 2013, dan 2014 untuk variabel laba per saham, nilai buku ekuitas dan arus kas operasi tidak saling berhubungan atau tidak terkalit satu tahun dengan tahun yang lain sehingga model regresi dalam penelitian ini tidak terjadi autokorelasi. 


\subsubsection{Uji Heteroskedastisitas}

Hasil pengujian autokorelasi dalam penelitian ini pada grafik scatterplot adalah sebagai berikut:

Gambar 1 Hasil Uji Heteroskedastisitas

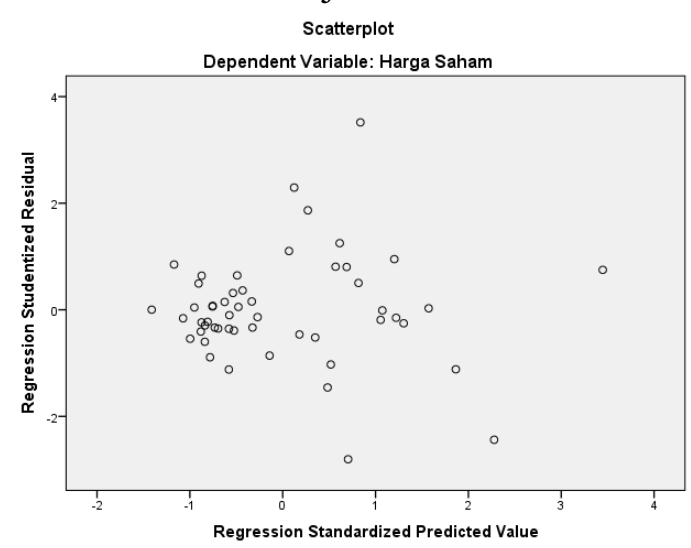

Sumber: Data diolah dari SPSS 20

Data ini sudah melalui tahap outlier

Hasil pengujian heteroskedasitas pada pengujian terhadap 52 data menunjukkan bahwa seluruh variabel sudah tidak teridentifikasi adanya heteroskedasitas yang ditunjukkan dengan tidak adanya pola yang jelas, serta titik-titik menyebar acak diatas dan dibawah pada angka 0 pada sumbu Y dalam grafik Scatterplot. Hal ini berarti bahwa nilai data telah bebas dari heteroskedasitas dan model regresi layak dipakai untuk memprediksi variabel dependen (harga saham) berdasarkan masukan sejumlah variabel independen (laba per saham, nilai buku ekuitas dan arus kas operasi).

\subsection{Uji Hipotesis}

\subsubsection{Uji Simultan (Uji F)}

Tabel 6 Hasil Uji Simultan (Uji F)

ANOVA $^{\mathrm{a}}$

\begin{tabular}{|c|c|c|c|c|c|c|}
\hline \multicolumn{2}{|c|}{ Model } & $\begin{array}{c}\text { Sum of } \\
\text { Squares }\end{array}$ & $d f$ & $\begin{array}{l}\text { Mean } \\
\text { Square }\end{array}$ & $F$ & Sig \\
\hline \multirow[b]{2}{*}{1} & $\begin{array}{l}\text { Regre } \\
\text { ssion }\end{array}$ & $\begin{array}{r}308578715 \\
.695\end{array}$ & 3 & $\begin{array}{r}102859 \\
571.898\end{array}$ & \multirow[t]{2}{*}{$\begin{array}{r}20 . \\
69 \\
5\end{array}$} & \multirow[t]{2}{*}{$\begin{array}{r}.00 \\
0^{\mathrm{b}}\end{array}$} \\
\hline & $\begin{array}{l}\text { Resid } \\
\text { ual } \\
\text { Total }\end{array}$ & $\begin{array}{r}238567481 \\
.613 \\
547146197 \\
.308 \\
\end{array}$ & 48 & $\begin{array}{r}497015 \\
5.867\end{array}$ & & \\
\hline
\end{tabular}

a. Dependent Variable: Harga Saham

b. Predictors: (Constant), Arus Kas Operasi, Laba Per Saham, Nilai Buku

Ekuitas

Sumber: Data diolah dari SPSS 20

Data ini sudah melalui tahap outlier

Berdasarkan hasil uji simultan (uji F) menunjukkan bahwa nilai $\mathrm{F}_{\text {hitung }}$ sebesar 20,695 dengan tingkat signifikansi sebesar $0,000^{\mathrm{b}}$ sedangkan untuk mencari $\mathrm{F}_{\text {tabel }}$ dapat diketahui dengan jumlah data $(n)=52$, jumlah variabel independen $(k)=3$ tingkat signifikan $(\alpha)=$ 0,05 maka dapat diketahui df $1=$ jumlah variabel $-1=4-1=3$ dan df $2=\mathrm{n}-\mathrm{k}-1=52$ $-3-1=48$ dengan menggunakan tabel distribusi $\mathrm{F}$ dan tingkat signifikansi 0,05 diperoleh $\mathrm{F}_{\text {tabel }}$ sebesar 2,80. 
Maka dapat disimpulkan bahwa $\mathrm{F}_{\text {hitung }}$ sebesar 20,695 sedangkan $\mathrm{F}_{\text {tabel }}$ sebesar 2,80 $\left(\mathrm{F}_{\text {hitung }}\right.$ $>\mathrm{F}_{\text {tabel }}$ ) dengan tingkat signifikansi $0,000<0,05$. Dengan demikian dapat disimpulkan bahwa laba per saham, nilai buku ekuitas dan arus kas operasi secara simultan memiliki pengaruh secara signifikan terhadap harga saham.

\section{Koefisien Determinasi $\left(\mathbf{R}^{2}\right)$}

Tabel 7 Hasil Uji Koefisien Determinasi $\left(\mathrm{R}^{2}\right)$ Model Summary ${ }^{\mathrm{b}}$

\begin{tabular}{clrr}
\hline Model & $R$ & $R$ Square & Adjusted $R$ Square \\
\hline 1 & $.751^{\mathrm{a}}$ & .564 & .537 \\
\hline
\end{tabular}

a. Predictors: (Constant), Arus Kas Operasi, Laba Per Saham, Nilai

Buku Ekuitas

b. Dependent Variable: Harga Saham

Sumber: Data diolah dari SPSS 20

Data ini sudah melalui tahap outlier

Berdasarkan tabel 7 diketahui bahwa nilai koefisien determinasi $\left(\mathrm{R}^{2}\right)$ dari Adjusted $R$ Square sebesar 0,537. Hal ini menunjukkan bahwa harga saham mampu dijelaskan oleh laba per saham, nilai buku ekuitas, dan arus kas operasi sebesar 53,7\%. Sedangkan sisanya yaitu $46,3 \%$ dapat dijelaskan oleh faktor lain yang tidak diteliti dalam penelitian ini seperti dividen, komisaris independen dan ukuran perusahaan.

\subsubsection{Uji Parsial (Uji t)}

Tabel 8 Hasil Uji Parsial (Uji t)

Coefficients $^{\mathrm{a}}$

\begin{tabular}{clrc}
\hline & Model & \multicolumn{1}{c}{$t$} & Sig. \\
\hline \multirow{4}{*}{1} & (Constant) & 3.473 & .001 \\
& Laba Per Saham & 4.154 & .000 \\
& Nilai Buku Ekuitas & -2.770 & .008 \\
& Arus Kas Operasi & 2.611 & .012 \\
\hline
\end{tabular}

a. Dependent Variable: Harga Saham

Sumber: Data diolah dari SPSS 20

Data ini sudah melalui tahap outlier

Untuk menentukan pengaruh atau tidaknya suatu penelitian secara parsial maka harus ditentukan terlebih dahulu $t_{\text {tabel }}$ nya. Adapun cara mencari $t_{\text {tabel }}$ adalah dengan jumlah sampel $(n)=52$, jumlah variabel independen $=3$, taraf signifikansi $(\alpha)=0,025$, maka derajat kebebasan $(\mathrm{df})=52-3-1=48$. Dengan menggunakan tabel distribusi t dan taraf signifikansi 0,025 diperoleh nilai $t_{\text {tabel }}$ sebesar 2,01063.

Variabel laba per saham (LPS) berdasarkan hasil uji pada tabel 8 mempunyai nilai $\mathrm{t}_{\text {hitung }}$ sebesar 4,154 sedangkan nilai $t_{\text {tabel }}$ sebesar 2,01063, maka $t_{\text {hitung }}>t_{\text {tabel }}$ dengan tingkat signifikansi 0,000. Karena nilai signifikansi $<0,05$ (dibawah 0,05), maka hipotesis $\mathrm{H}_{0}$ ditolak dan hipotesis $\mathrm{H}_{1}$ diterima artinya bahwa laba per saham memiliki pengaruh yang signifikan terhadap harga saham (HS).

Variabel nilai buku ekuitas berdasarkan hasil uji pada tabel 8 mempunyai nilai $\mathrm{t}_{\text {hitung }}$ sebesar 2,770 sedangkan nilai $t_{\text {tabel }}$ sebesar 2,01063, maka $t_{\text {hitung }}>t_{\text {tabel }}$ dengan tingkat signifikansi 0,008. Karena nilai signifikansi $<0,05$ (dibawah 0,05), maka hipotesis $\mathrm{H}_{0}$ ditolak dan hipotesis $\mathrm{H}_{1}$ diterima artinya bahwa nilai buku ekuitas memiliki pengaruh yang signifikan terhadap harga saham (HS).

Variabel arus kas operasi (AKO) berdasarkan hasil uji pada tabel 8 mempunyai nilai $t_{\text {hitung }}$ sebesar 2,661 sedangkan nilai $t_{\text {tabel }}$ sebesar 2,01063, maka $t_{\text {hitung }}>t_{\text {tabel }}$ dengan tingkat signifikansi 0,012. Karena nilai signifikansi $<0,05$ (dibawah 0,05), maka hipotesis $\mathrm{H}_{0}$ 
ditolak dan hipotesis $\mathrm{H}_{1}$ diterima artinya bahwa arus kas operasi memiliki pengaruh yang signifikan terhadap harga saham (HS).

\subsection{Analisis Regresi Berganda}

Tabel 9 Hasil Uji Regresi Berganda

Coefficients $^{\mathrm{a}}$

\begin{tabular}{llrr}
\hline \multirow{2}{*}{ Model } & \multicolumn{1}{c}{ Unstandardized Coefficients } \\
\cline { 2 - 4 } & (Constant) & 1848.399 & Std. Error \\
\hline & Laba Per Saham & 10.730 & 2.286 \\
1 & Nilai Buku Ekuitas & -1.131 & .408 \\
& Arus Kas Operasi & 4.852 & 1.859 \\
\hline
\end{tabular}

a. Dependent Variable: Harga Saham

Sumber: Data diolah dari SPSS 20

Data ini sudah melalui tahap outlier

$\mathrm{HS}=1.848,399+10,730 \mathrm{LPS}-1,131 \mathrm{NBE}+4,852 \mathrm{AKO}$

Keterangan:

HS = Harga Saham

LPS = Laba Per Saham

NBE $\quad$ Nilai Buku Ekuitas

$\mathrm{AKO}=$ Arus Kas Operasi

Dari persamaan diatas diketahui bahwa konstanta sebesar 1.848,399 menyatakan bahwa jika laba per saham, nilai buku ekuitas, dan arus kas operasi bernilai konstan, maka harga saham bernilai sebesar 1.848,399 artinya jika laba per saham, nilai buku ekuitas, dan arus kas operasi bernilai konstan, maka besarnya harga saham adalah Rp $1.848,399$.

Laba per saham mempunyai koefisien regresi sebesar 10,730 menyatakan bahwa setiap penambahan sebesar Rp 1 laba per saham (dengan asumsi bahwa nilai koefisien variabel lain tetap atau tidak berubah), maka harga saham pada perusahaan akan mengalami kenaikan sebesar Rp 10,730. Namun sebaliknya, jika laba per saham turun Rp 1 (dengan asumsi bahwa nilai koefisien variabel lain tetap atau tidak berubah), maka harga saham pada perusahaan akan mengalami penurunan sebesar Rp 10,730.

Nilai buku ekuitas mempunyai koefisien regresi sebesar -1,131 menyatakan bahwa setiap penambahan sebesar Rp 1 nilai buku per lembar saham (dengan asumsi bahwa nilai koefisien variabel lain tetap atau tidak berubah), maka harga saham akan mengalami penurunan sebesar $\mathrm{Rp}$ 1,131. Namun sebaliknya, jika nilai buku per lembar saham turun sebesar Rp 1 (dengan asumsi bahwa nilai koefisien variabel lain tetap atau tidak berubah), maka harga saham akan mengalami kenaikan sebesar Rp 1,131 .

Arus kas operasi (AKO) mempunyai koefisien regresi sebesar 4,852 menyatakan bahwa setiap penambahan Rp 1 arus kas operasi per lembar saham (dengan asumsi bahwa nilai koefisien variabel lain tetap atau tidak berubah), maka harga saham diindikasikan mengalami kenaikan sebesar Rp 4,852. Namun sebaliknya, jika arus kas operasi per lembar saham turun sebesar Rp 1 (dengan asumsi bahwa nilai koefisien variabel lain tetap atau tidak berubah), maka harga saham diindikasikan akan mengalami penurunan sebesar Rp 4,852. 


\section{PEMBAHASAN}

Pengujian hipotesis secara simultan berdasarkan tabel ANOVA memberikan bukti bahwa laba per saham, nilai buku ekuitas dan arus kas operasi memiliki pengaruh yang signifikan secara bersama-sama terhadap harga saham.

\subsection{Pengaruh Laba Per Saham Terhadap Haga Saham}

Penelitian ini telah menunjukkan bahwa variabel laba per saham berpengaruh signifikan terhadap harga saham yang diukur dengan merata-ratakan harga saham selama 5 hari setelah tanggal publikasi. Sehingga dapat disimpulkan bahwa besar kecilnya laba bersih dapat mempengaruhi tinggi rendahnya harga saham (keputusan pembelian saham). Hal ini disebabkan karena laba per saham dapat digunakan dalam mengevaluasi kinerja operasi dan profitabilitas perusahaan, oleh karena itu para investor menyukai perusahaan yang melaporkan nilai laba per lembar saham. Selain itu, seorang investor membeli dan mempertahankan saham dengan harapan akan memperoleh dividen atau capital gain. Laba biasanya menjadi dasar penentuan pembayaran dividen dan kenaikan nilai saham di masa mendatang. Sehingga, semakin tinggi nilai laba per saham yang dikarenakan oleh semakin besar laba yang diperoleh akan meningkatkan harga pasar saham, begitupun sebaliknya. Hasil penelitian ini, mendukung penelitian yang dilakukan oleh Ball \& Brown (1968) dalam Adhani \& Subroto (2014) yang menunjukkan bahwa investor memperhatikan kemampuan perusahaan dalam menghasilkan laba bersih pada setiap lembar saham untuk keputusan pembelian saham. Hasil penelitian ini mendukung penelitian yang telah dilakukan oleh Susanto \& Ekawati (2006), Cahyonowati \& Ratmono (2012), Shamki \& Rahman (2012) dan Adhani \& Subroto (2014). Namun hasil penelitian ini tidak mendukung penelitian yang dilakukan oleh Sari (2014), Rahmawato (2005), Tsalavoutas, et all (2012) dan Rosari (2014).

\subsection{Pengaruh Nilai Buku Ekuitas Terhadap Haga Saham}

Penelitian ini telah menunjukkan bahwa nilai buku ekuitas memiliki pengaruh signifikan negatif terhadap harga saham. Sehingga apabila terjadi penurunan pada nilai buku ekuitas maka akan meningkatkan harga saham. Perusahaan yang mengalami keuntungan maka perusahaan akan membagikan dividen, karena pada dasarnya para investor ingin melakukan investasi dalam bentuk saham agar para investor mendapatkan keuntungan dari hasil menanamkan dananya yaitu salah satunya berupa dividen. Dividen akan mengurangi nilai retained earning sehingga nilai ekuitas akan mengalami penurunan. Selain itu saham treasuri tidak termasuk dalam aktiva namun termasuk dalam ekuitas. Ketika saham treasuri dibeli, maka terjadi pengurangan baik pada aktiva maupun ekuitas pemegang saham. Menurut Kieso (2011, hlm.777), salah satu alasan perusahaan membeli sahamnya kembali adalah untuk meningkatkan laba per saham dan pengembalian atas ekuitas (ROE). Sehingga dapat disimpulkan bahwa tinggi rendahnya nilai buku ekuitas dapat mempengaruhi tinggi rendahnya harga saham (keputusan pembelian saham). Penelitian ini konsisten dengan penelitian Minhalina \& Nazaruddin (2014) yang menyatakan bahwa pasar lebih tertarik untuk melihat informasi nilai laba dibandingkan nilai buku. Hal ini bisa disebabkan adanya pembagian deviden yang besar karena perusahaan menghasilkan laba yang besar. Hasil penelitian ini mendukung penelitian yang telah dilakukan oleh Indra \& Syam (2004), Sari (2004), Cahyonowati \& Ratmono (2012), Rosari (2014) dan Adhani \& Subroto (2014). Namun hasil ini tidak mendukung penelitian yang dilakukan oleh Tsalavoutas, et al (2012) dan Shamki \& Rahman (2012). 


\subsection{Pengaruh Arus Kas Operasi Terhadap Haga Saham}

Penelitian ini telah menunjukkan bahwa variabel arus kas operasi berpengaruh signifikan positif terhadap harga saham. Besar kecilnya arus kas operasi dapat memiliki pengaruh terhadap harga saham (keputusan pembelian saham). Hal ini disebabkan karena para investor beranggapan bahwa kemampuan prediksi arus kas operasi dapat digunakan untuk pertimbangan dalam mengambil keputusan membeli saham. Dalam laporan arus kas operasi para investor dapat mengetahui rincian sumber penerimaan dan pengeluaran kas serta mengenai kinerja perusahaan dalam periode tertentu berdasarkan aktivitas operasi perusahaan tersebut mulai dari produksi hingga penjualan. Selain itu arus kas yang timbul dari aktivitas operasi adalah indikator utama untuk menentukan apakah operasi entitas telah menghasilkan arus kas yang cukup untuk melunasi pinjaman, memelihara kemampuan operasi entitas, membayar dividen, dan melakukan investasi baru tanpa bantuan sumber pendanaan dari luar. Penelitian ini konsisten dengan penelitian Susanto \& Ekawati (2006) yang menyatakan bahwa perusahaan yang mampu menghasilkan laba positif serta aliran kas operasi yang positif menunjukkan keberhasilan dalam memperoleh pangsa pasar, perusahaan yang memiliki aliran kas operasi yang positif dan tinggi menunjukkan bahwa perusahaan sudah mapan dan mampu membiayai pertumbuhan penjualannya, dan perusahaan yang memiliki aliran kas operasi positif mengandung informasi tentang kemampuan perusahaan mampu menghasilkan modal atas kegiatan operasinya sendiri, yakni untuk membayar kepada para debitur dalam kasus likuidasi. Hasil penelitian ini mendukung penelitian yang dilakukan oleh Sari (2004), Rahmawati (2005), dan Susanto \& Ekawati (2006). Namun hasil ini penelitian sebelumnya tidak mendukung penelitian yang telah dilakukan oleh Meythi (2006), Adhani \& Subroto (2014), dan Sa'adah \& Kadarusman (2014).

\subsection{Keterbatasan Penelitian}

Dalam penelitian ini terdapat beberapa keterbatasan yang mepengaruhi hasil dalam penelitian ini yaitu tidak semua data perusahaan memenuhi kriteria yang telah ditentukan sehingga sampel yang dipergunakan sedikit dan data semua variabel memiliki standar deviasi yang lebih besar sehingga memiliki nilai simpangan yang besar.

\section{KESIMPULAN}

Setelah melakukan analisis data dan pengujian hipotesis pengaruh laba per saham, nilai buku ekuitas dan arus kas operasi terhadap harga saham pada 44 perusahaan sektor manufaktur yang terdaftar di Bursa Efek Indonesia (BEI) untuk tahun 2012 sampai dengan 2014 dapat ditarik kesimpulan bahwa secara simultan laba per saham, nilai buku ekuitas dan arus kas operasi secara simultan memiliki pengaruh secara signifikan terhadap harga saham. Secaara parsial laba per saham memiliki pengaruh signifikan positif terhadap harga saham, nilai buku ekuitas memiliki pengaruh signifikan negatif terhadap harga saham dan arus kas operasi berpengaruh signifikan positif terhadap harga saham yang diukur dengan merata-ratakan harga saham selama 5 hari setelah tanggal publikasi.

\section{DAFTAR PUSTAKA}

Adhani, YS \& Subroto, B 2014, 'Relevansi nilai informasi akuntansi', Jurnal Ilmiah FEB, vol.2, no.2, 2013, hlm.1-15. 
Bursa Efek Indonesia, Laporan keuangan, diakses tanggal 20 September 2015, http://www.idx.co.id.

Cahyonowati, N \& Ratmono, D 2012, 'Adopsi IFRS dan relevansi nilai informasi akuntansi', Jurnal Akuntansi dan Keuangan, vol.14, no.1, November 2012, hlm.105115.

Fahmi, I 2012, Pengantar pasar modal, Alfabeta, Bandung.

Ghozali, I 2013, Aplikasi analisis multivariate dengan program IBM SPSS 21 update PLS regresi, Badan Penerbit Universitas Diponegoro, Semarang.

Godfrey, J, Hodgson, A, Tarca, A, Hamilton, J, Holmes, S 2010, Accounting theory, 7th edition, Wiley, Australia.

Hadi, N 2013, Pasar modal: Acuan teoritis dan praktis investasi di instrumen keuangan pasar modal, Graha Ilmu, Yogyakarta.

Halim, A 2015, Analisis investasi dan aplikasinya, Salemba Empat, Jakarta.

Harahap, SS 2012, Teori akuntansi, Edisi Revisi 2011, PT Raja Grafindo Persada, Jakarta.

Hartono, J 2010, Teori portofolio dan analisis investasi, BPFE-Yogyakarta, Yogyakarta.

Hermuningsih, S 2012, Pengantar pasar modal indonesia, UPP STIM YKPN, Yogyakarta.

Hery 2015, Analisis kinerja manajemen, Grasindo, Jakarta.

Indonesia Capital Market Electronic Library (ICAMEL), Laporan keuangan, diakses tanggal 28 Oktober 2015,

Indonesia Capital Market Electronic Library (ICAMEL), Data tanggal publikasi, diakses tanggal 6 November 2015.

Ikatan Akuntansi Indonesia 2014, Standar akuntansi keuangan: Per efektif 1 Januari 2015, Ikatan Akuntansi Indonesia, Jakarta.

Indra \& Syam, F 2004, 'Hubungan laba akuntansi, nilai buku, dan arus kas dengan market value: Studi akuntansi relevansi nilai', Simposium Nasional Akuntansi 7, Denpasar, Bali, hlm.1-23.

Kasmir 2012, Analisis laporan keuangan, PT. Raja Grafindo Persada, Jakarta.

Kieso, DE, Weygandt, JJ \& Warfield, TD 2011, Intermediate accounting, vol 2, John Wiley \& Sons, Inc, United States of America.

Martalena \& Malinda, M 2011, Pengantar pasar modal, Andi, Yogyakarta.

Meythi 2006, 'Pengaruh arus kas operasi terhadap harga saham dengan persistensi laba sebagai variabel intervening', Simposium Nasional Akuntansi 9, Padang, 23-26 Agustus 2006, hlm.1-24. 
Puspitaningtyas, Z 2012, 'Relevansi nilai informasi akuntansi dan manfaatnya bagi investor', Ekuitas: Jurnal Ekonomi dan Keuangan, hlm.164-183.

Rahmawati 2005, 'Relevansi nilai informasi akuntansi dengan pendekatan terintegrasi hubungan nonlinier', Simposium Nasional Akuntansi 8, 15-16 September 2005, hlm.308-324.

Rosari, EV 2014, 'Relevansi laba akuntansi dan nilai buku terhadap harga saham dengan moderasi corporate governance pada perusahaan yang terdaftar di BEI tahun 20102012', Jurnal Ilmiah Mahasiswa Universitas Surabaya, vol.3, no.2, hlm.1-15.

Sa'adah, L \& Kadarusman 2014. 'Pengaruh laba akuntansi, komponen arus kas, ukuran perusahaan terhadap harga saham pada perusahaan kelompok LQ 45 yang listing di bursa efek indonesia'. Jurnal Manajemen dan Akuntansi, vol.3, no.2, hlm.16-30.

Santoso, S 2014, Panduan lengkap SPSS versi 20, Elex Media Komputindo, Jakarta.

Santoso, S 2014, Statistik multivariat, Elex Media Komputindo, Jakarta.

Sari, SM 2004, 'Analisa terhadap relevansi (value-relevance) laba, arus kas, dan nilai buku ekuitas : Analisa diseputar perioda krisis keuangan 1995-1998', Simposium Nasional Akuntansi 7, Denpasar 2004, hlm.1-32.

Scott, WR 2011, Financial accounting theory, Toronto, Prentice-Hall International, Canada.

Shamki, D \& Rahman, AA 2012, 'Value relevance of earnings and book value: Evidence from Jordan', International Journal of Business and Management', hlm.133-141.

Simatupang, M 2010, Pengetahuan praktis investasi saham dan reksa dana, Mitra Wacana Media, Jakarta.

Sitanggang, JP 2012, Manajemen keuangan perusahaan, Mitra Wacana Media, Jakarta.

Subramanyam, KR \& Wild, JJ 2004, Analisis laporan keuangan, Salemba Empat, Jakarta.

Sukestiyarno 2013, Statistik dasar, Andi, Yogyakarta.

Sugiyono 2011, Metode penelitian kombinasi, Alfabeta, Bandung.

Susanto, S \& Ekawati, E 2006, 'Relevansi nilai informasi laba dan aliran kas terhadap harga saham dalam kaitannya dengan siklus hidup perusahaan', Simposium Nasional Akuntansi 9, Padang, 23-26 Agustus 2006, hlm.1-21.

Suwardjono 2010, Teori akuntansi perekayasaan pelaporan keuangan, Edisi Ketiga, BPFE-Yogyakarta, Yogyakarta.

Tandelilin, E 2010, Portofolio dan investasi, Kanisius, Yogyakarta.

Tsalavoutas, I, Andre, P, Evans, L 2012, 'The transition to IFRS and the value relevance of financial statements in greece', The British Accounting Review, May 2012, hlm.262-277. 
Universitas Pembangunan Nasional "Veteran" Jakarta 2014, Pedoman penulisan karya ilmiah bagi dosen dan mahasiswa, Lembaga Penelitian dan Pemberdayaan Masyarakat, Jakarta.

Wirama, DG 2008, 'Teori surplus bersih: Valuasi perusahaan berdasarkan data akuntansi', Jurnal Akuntansi, vol.3, no.2, hlm.205-215.

Yahoo Finance, Harga saham, diakses tanggal 20 September 2015, http://www.yahoo.finance.com. 